\section{THU0209 LYMPHOCYTE SUBSETS IN BIOPSY SPECIMEN ARE ASSOCIATED WITH SPONTANEOUS REGRESSION OF LYMPHOPROLIFERATIVE DISORDERS IN RHEUMATOID ARTHRITIS PATIENTS TREATED WITH METHOTREXATE}

T. Kameda ${ }^{1}$, M. Izumikawa ${ }^{1}$, M. Inoo ${ }^{2}$, I. Onishi ${ }^{2}$, N. Kurata ${ }^{2}$, S. Nakashima ${ }^{1}$, H. Shimada ${ }^{1}$, H. Ozaki ${ }^{1}$, R. Wakiya ${ }^{1}$, A. Kondo ${ }^{1}$, N. Kadowaki ${ }^{1}$, H. Dobashi ${ }^{1}$. ${ }^{1}$ Department of internal medicine division of endocrinology and metabolism, Hematology, Rheumatology and Respiratory Medicine, Kagawa University; 2 Internal medicine, Utazu hospital, Kagawa, Japan

Background: Patients with rheumatoid arthritis (RA) have a high risk for lymphoproliferative disorders (LPDs). An LPD in a patient treated with methotrexate (MTX) is known as MTX-associated LPD (MTX-LPD), which is classified among immunodeficiency-associated lymphoproliferative disorders (ID-LPD) as "other iatrogenic ID-LPD" in the 2008 World Health Organization Classification of Tumours of Haematopoietic and Lymphoid Tissues (1). We previously reported that MTX is an independent risk factor for LPD onset in Japanese patients with RA (2). In MTX-LPD, MTX withdrawal can result in spontaneous regression of LPD. In addition, limited evidence indicates that Epstein-Barr virus infection is related to spontaneous regression of MTX-LPD. No biomarker has been identified that predicts spontaneous regression of MTX-LPD.

Objectives: To identify a biomarker that predicts spontaneous regression of MTX-LPD in RA patients.

Methods: We enrolled RA patients from Kagawa Prefecture, Japan, who developed MTX-LPD during the period from June 2010 through December 2016. RA was diagnosed in accordance with the American College of Rheumatology 1987 classification criteria and was treated with disease-modifying antirheumatic drugs, including MTX. The patients were divided into two groups: those followedup after discontinuation of MTX alone (MTX withdrawal group) and those who received chemotherapy at 1 month or later after MTX discontinuation (chemotherapy group). The following variables were compared between groups: change in peripheral lymphocyte subsets after MTX discontinuation, serum soluble interleukin-2 receptor, and lymphocyte subsets and Epstein-Barr virus-encoded RNAs in a biopsy specimen from a lesion.

Results: We enrolled 43 MTX-LPD patients (29 in the withdrawal group and 14 in the chemotherapy group). From among these groups, we selected 32 patients for analysis of changes in peripheral lymphocyte subsets (23 in the withdrawal group and 9 in the chemotherapy group) and 22 for analysis of lymphocyte subsets in a lesion specimen (11 each in the withdrawal group and chemotherapy group). Peripheral lymphocyte counts were significantly higher after MTX discontinuation in the withdrawal group. Analysis of lymphocyte subsets from lesion specimens revealed significantly higher CD8-positive lymphocyte counts in the chemotherapy group than in the withdrawal group.

Conclusions: Lymphocyte count differed before and after MTX discontinuation, and a higher CD8-positive lymphocyte count in a lesion specimen was associated with spontaneous regression of MTX-LPD. These findings may help identify a predictive marker for MTX-LPD treatment and management.

References:

[1] Swerdlow SH, Campo E, Harris NL, Jaffe ES, Pileri SA, Stein H, et al., WHO Classification of Tumours of Haematopoietic and Lymphoid Tissues. IARC Press, Lyon, 2008.

[2] Association of higher methotrexate dose with lymphoproliferative disorders onset in rheumatoid arthritis patients. Kameda T, Dobashi H, Miyatake N, Inoo M, Onishi I, Kurata N, Mitsunaka H, Kawakami K, Fukumoto T, Susaki K, Izumikawa M, Nakashima S, Shimada H, Takeuchi Y, Haba R, Mano S, Onishi H, Imataki O, Matsunaga T. Arthritis Care Res (Hoboken). 2014 Sep;66(9):1302-9.

Disclosure of Interest: None declared

DOI: 10.1136/annrheumdis-2017-eular.4683

\section{THU0210 CHANGES IN HEMOGLOBIN LEVELS UPON TREATMENT WITH ABT-494, A SELECTIVE JAK-1 INHIBITOR, AND RELATION TO BASELINE LEVELS OF C-REACTIVE PROTEIN}

V. Strand ${ }^{1}$, M. Genovese ${ }^{1}$, J. Kremer ${ }^{2}$, M. Schiff ${ }^{3}$, Y. Li $^{4}$, J. Sokolove ${ }^{4}$. ${ }^{1}$ Stanford Univ, Palo Alto; ${ }^{2}$ Albany Medical College, Albany, NY; ${ }^{3}$ Univ of Colorado, Denver, CO; ${ }^{4}$ AbbVie, N Chicago, IL, United States

Background: Patients (pts) with rheumatoid arthritis (RA) often have inflammation-related anemia of chronic disease, partially due to IL-6 and its induction of hepcidin. High levels of the inflammatory marker $\mathrm{C}$-reactive protein (CRP) are largely induced by IL-6. Treatment with JAK inhibitors has been associated with both rise and fall in hemoglobin $(\mathrm{Hb})$ levels, possibly due to inflammation control and inhibition of JAK2 (which is involved in erythropoiesis), respectively 1,2

Objectives: To examine the association of changes in $\mathrm{Hb}$ upon treatment with ABT-494 with baseline (BL) CRP levels.

Methods: This post hoc analysis used data from two phase $2 \mathrm{~b}$ randomized controlled trials (RCT) of ABT-494: in RA pts with inadequate responses or intolerance to TNF inhibitors (TNF-IR, BALANCE-1) , $^{3}$, and in pts with inadequate responses to methotrexate (MTX-IR, BALANCE-2) ${ }^{4}$. The analyses included pts receiving ABT-494 at 6 or $12 \mathrm{mg}$. Pts were subgrouped by quartiles of $B L C R P$. For each RCT, and for the pooled data from both, changes from $\mathrm{BL}$ in $\mathrm{Hb}(\mathrm{g} / \mathrm{dL})$ were determined after 12 weeks (wk) of treatment with ABT-494, for the overall population and for pts who achieved ACR20 or DAS28-CRP $\leq 3.2$ responses at Wk 12. For ACR20 and DAS28-CRP $\leq 3.2$, non-responder imputation was used. For changes in $\mathrm{Hb}$, data are as observed. Significance was determined by ANCOVA.

Results: In pooled data from 110 and 100 pts from BALANCE-1 and -2 respectively, higher $\mathrm{BL} C R P$ was associated with smaller mean decreases in $\mathrm{Hb}$ at Wk $12(\mathrm{p}=.074)$. In the MTX-IR trial, pts in the highest CRP quartile had a mean increase from $\mathrm{BL}$ in $\mathrm{Hb}(+0.28 \mathrm{~g} / \mathrm{dL})$ vs pts in the lower quartiles who had mean decreases in $\mathrm{Hb}(\mathrm{p}<.01)$. In both RCTs, ACR20 or DAS28-CRP $\leq 3.2$ responders had smaller decreases in $\mathrm{Hb}$ vs non-responders at Wk 12. Among DAS28-CRP $\leq 3.2$ responders, pts in the higher CRP quartiles had significantly smaller mean decreases in $\mathrm{Hb}$ vs pts in the lower quartiles $(\mathrm{p}<.01$ for MTX-IR and $\mathrm{p}<.05$ for TNF-IR pts). Responders in the highest BL CRP quartile also had a mean increase in $\mathrm{Hb}(+0.31$ and $+0.54 \mathrm{~g} / \mathrm{dL}$ for MTX-IR ACR20 and DAS28-CRP $\leq 3.2$ responders respectively, $+0.15 \mathrm{~g} / \mathrm{dL}$ for TNF-IR DAS28-CRP $\leq 3.2$ responders) (Fig. 1A-D). While similar trends between BL CRP levels and changes in $\mathrm{Hb}$ at Wk 12 were observed among ACR20 or DAS28-CRP $\leq 3.2$ non-responders, the differences in $\mathrm{Hb}$ levels between the quartiles were not significant. Despite the small mean changes, the mean $\mathrm{Hb}$ values remained within the normal range for females (lower limit of normal $11.5 \mathrm{~g} / \mathrm{dL}$ )

Figure 1. Hb levels at BL and Week 12 in patients by baseline CRP quartile in patients who achieved an ACR2O or LDA response.

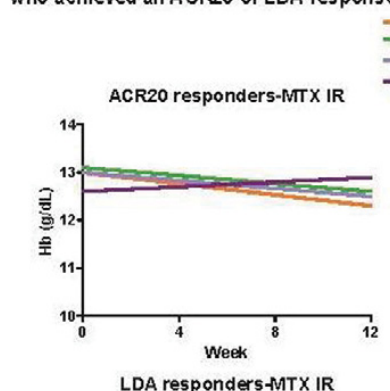

$$
\begin{aligned}
& =01 \\
& =\quad 02 \\
& =\quad 03 \\
& -\quad 04
\end{aligned}
$$
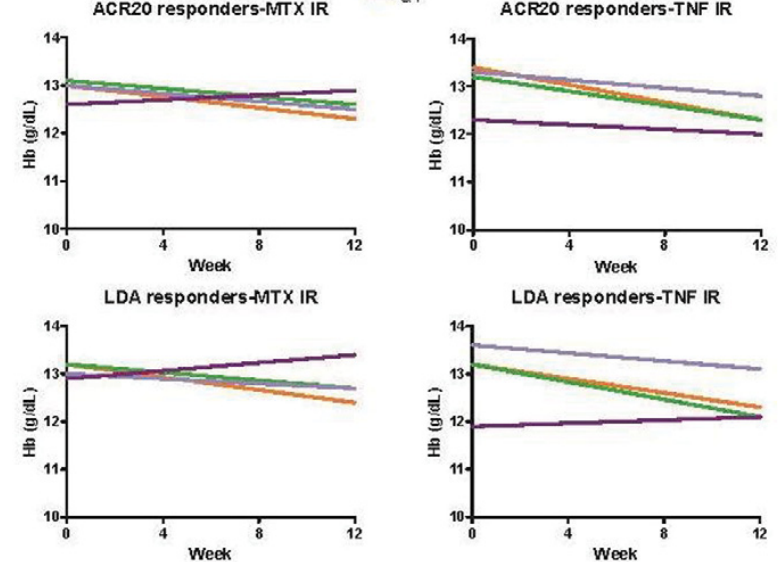
Q1 is the lowest, and $Q 4$ the highest quartile. $Q 1$ was within the normal range, for which the
upper limit is $5 \mathrm{mg} / \mathrm{L}$. CRP quartile cutoffs are as follows. In MTX-IR, Q1: $\leq 2.5 \mathrm{mg} / \mathrm{L}, \mathrm{Q} 2>2$. and $\leq 5.9 \mathrm{mg} / \mathrm{L}, Q 3:>5.9$ and $\leq 18.3 \mathrm{mg} / \mathrm{L}, Q 4:>18.3 \mathrm{mg} / \mathrm{L}$; in TNF-IR, Q1: $\leq 3.1 \mathrm{mg} / \mathrm{L}, Q 2:>3$ and $\leq 7.0 \mathrm{mg} / \mathrm{L}, Q 3:>7.0$ and $\leq 16.7 \mathrm{mg} / \mathrm{L}, Q 4:>16.7 \mathrm{mg} / \mathrm{L}$.

Conclusions: Upon treatment with ABT-494, pts with the highest CRP (a potential surrogate for $(\mathrm{L}-6)$ at $\mathrm{BL}$ had a mean increase in $\mathrm{Hb}$ compared to decreases in those with lower CRP. This effect was more apparent in pts with clinical responses. This suggests that effective treatment of RA-associated inflammation with ABT-494 may counterbalance the small $\mathrm{Hb}$ reduction associated with JAK inhibition.

\section{References:}

[1] Schulze-Koops et al 2017, Rheumatology;56:46.

[2] Genovese et al 2016, NEJM; 374:13.

[3] Kremer et al 2016, Arthritis \& Rheum;68:2867.

[4] Genovese et al 2016, Arthritis \& Rheum;68:2857.

Acknowledgements: AbbVie: Study sponsor, involved in study design, data collection, analysis, and interpretation, and in publication writing, review, and final approval. Medical writing: Naina Barretto, of AbbVie.

Disclosure of Interest: V. Strand Consultant for: AbbVie, Afferent, Amgen, Biogen Idec, Bioventus, BMS, Carbylan, Celgene, Celltrion, CORRONA, Crescendo, Genentech/Roche, GSK, Hospira, Iroko, Janssen, Lilly, Merck, Novartis, Pfizer, Regeneron, Sanofi, SKK, Takeda, UCB, Vertex, M. Genovese Grant/research support from: AbbVie, Lilly, Astellas, Vertex, Pfizer, Galapagos, Gilead, Consultant for: AbbVie, Lilly, Astellas, Vertex, Pfizer, Galapagos, Gilead, J. Kremer Grant/research support from: AbbVie, Lilly, Novartis, Pfizer, Medlmmune, Sanofi, and Regeneron, Consultant for: AbbVie, Lilly, Novartis, Pfizer, Medlmmune, Sanofi, and Regeneron, Employee of: CORONA, M. Schiff Consultant for: AbbVie, Speakers bureau: AbbVie, Y. Li Employee of: AbbVie, J. Sokolove Employee of: AbbVie

DOI: 10.1136/annrheumdis-2017-eular.3216 